\title{
Determinants of Industry - University Linkages and Their Impacts on Firm Performance, in Western Ethiopia: Implication for Technology Transfer.
}

\author{
Gemechu Bekana
}

Department of Statistics, Faculty of Natural and Computational Science, Mettu University, Ethiopia, P. O. Box: 318

\begin{abstract}
This paper utilizes the western Ethiopia Innovation Survey data to find out the determinants of industry-university cooperation and its impact on firm performance. We find first that among determinants of Industry-university cooperation, traditional firm characteristics variables of sizes and $R \& D$ intensity are not significant at all, while the participation at the national $R \& D$ project turns out be most significant and robust in both cooperation modes. This is in quite contrast to the results from the cases of western Ethiopia, and reflects importantly the heavy weight of government policies in promoting the Industry-university cooperation in latecomer economies. Second, regarding the impacts of the Industry-university cooperation, we strikingly find no significant impact on the innovation probability of firms when we control the possible endogeneity such that already innovative firms might participate more at such cooperation modes. This implies that the Industry-university cooperation cannot guarantee a firm success in technological innovation; rather, it may have an influence on the selection or direction of the firm's research projects. When we limit the analysis to the innovative firms, we do find positive impacts of the Industry-university cooperation on patents generated from new product innovation but no impacts in terms of sales increase or labor productivity. These results seem to reflect the still transitional nature of the NIS and knowledge industrialization.
\end{abstract}

Keywords: University, Industry, Innovation, Firm and western Ethiopia

\section{Introduction}

Universities play a crucial role in society as producers and transmitters of knowledge. In recent years the discussion about whether academia can encompass a third mission of economic development, in addition to research and teaching, has received greater attention (Etzkowitz \& Leydesdorff, 2000). In the knowledge-based economy, knowledge is essential; thus the role of university as a source of new knowledge has even become more important than in the past ( Etzkowitz et al., 2000). Fast-paced global competition and technological change also add significance to the firm's links to university for not only discovery of knowledge but also its industrialization (Bettis and Hitt, 1995; Etzkowitz and Leydesdorff, 1997; Hwang et al., 2003). In other words, the universities and public research institutes have emerged as the key component of the national innovation system (NIS) which was proposed by Freeman (2006).

Gibbons and Johnston (2006) defines the NIS as a "network of institutions in the public and private sectors whose activities and interactions initiate, import, modify, and diffuse new technologies." Free defines it as the "elements and relationships which interact in the production, diffusion, and use of new, and economically useful, knowledge... and are either located within or rooted inside the borders of a nation state." He broadens the concept of Freeman to include economic structure and institutional set-up that affect searching, learning, and adapting. In the NIS literature, one of the roles of universities and research institutes is to channel their knowledge to firms, and universities function as a knowledge diffuser by producing quality students and by interacting with firms through cooperative programs.
In the context of the above discussion, one of the possible contributions of this study is that we are examining the role of university in performance of firms and UIs, whereas the existing studies tend to focus more on firm-level and sectoral level characteristics, such as R\&D intensity, firm size (Capron, H. and M. Cincera. (2003)). Also, as UIs have been the key participants in these national $\mathrm{R} \& \mathrm{D}$ projects that involved private firms, it is important to examine the impact of Industry - university collaboration and impacts on firm performance.

Many scholars have argued that university-industry collaborations are extremely important mechanisms for generating technological spillovers, as they positively contribute to address innovation market failures and help to realize the full social returns of R\&D investments (Martin and Scott, 2007). Moreover, there is a burgeoning empirical literature showing an increasing level of academic commercial activities, such as patenting and licensing, and generation of spin-out companies This has been accompanied by an increase in research joint ventures (Hall et al, 2010), and in joint scientific publications (Calvert and Patel, 2012).

Freel and Harrison (2006 ) empirically prove the positive relationship between industry and university. This implies that industry-university cooperation may be helpful for product innovation, while industry-industry cooperation may for process innovation. Rouvinen (2002) supports this through an empirical analysis of data from manufacturing firms: that is, industry-university research organization contributes only to product innovation. The explain it such that process innovation benefits from the "stocks of capitalembodied technology," while product innovation does from the "disembodied forms of technology." They also mention the point that process innovation may constitute a part of 


\section{International Journal of Science and Research (IJSR) \\ ISSN (Online): 2319-7064}

Index Copernicus Value (2015): 78.96 | Impact Factor (2015): 6.391

product innovation rather than being patented (Chang, 2010).

While this paper addresses the questions what determines the IU (industry-university) linkages and how the linkages affect firm performances, it also achieves some methodological improvement. Some studies, for instance Monjon and Waelbroeck (2014), examining the impact on firm performance do not control possible endogeneity such that better performing firms might be more inclined to pursue collaboration with universities. We take a two-step approach. We first estimate the determinants of IU cooperation by Probit model regressions. Second, it estimates the impact of this cooperation on innovation performance where a possible endogeneity of IU cooperation measure is controlled by using the results of the first-step estimations. We consider the controlling endogeneity is important, because we have obtained contradictory results; when endogeneity is controlled, collaboration with universities is not shown to be significantly increasing the probability of innovation.

Also, when we examine the impact of the IU cooperation on firms' performance, we control a possible sample selection bias using Heckman's 2SLS method, and the types of innovation are differentiated into product vs. process innovation. The empirical analysis utilizes the data from the 2015 western Ethiopia Innovation Survey (WEIS) that was conducted by researcher. The WEIS comprises of firm-level data on technological innovation in the manufacturing sector. In order to allow for use of more variables and data credibility, the Survey data is merged with the standard financial statements of the firms compiled by a credit rating agency.

\subsection{Statement of the Problem}

To the best of my knowledge, there has been no study undertaken on the university-industry linkages. If we agree that university-industry linkage contributes to technology transfer and determines the firm products of the country. It is also important to study the factors that determine the university-industry linkages in western Ethiopia.

There are limited researches conducted on universityindustry linkages and its correlates with firm products Ethiopia. The implication is that the technology transfer for firm performance was not given attention in Ethiopia, particularly, in western Ethiopia. Beside this, most research papers focuses on the linkages of university and industry. Identifying the impacts of University-Industry linkages on the firm performance and national innovation becomes sound enough to put an agenda on the poor, targeting of policy makers in intervening on that particular study area.

This study focuses on the determinants of Industry University Linkages and Their Impacts on Firm Performance, in Western Ethiopia for the Implication of Technology Transfer.

\subsection{Objectives of the Study}

The Main objective of the study is to identify the Determinants of Industry - University Linkages and Their Impacts on Firm Performance, in Western Ethiopia: Implication for Technology Transfer. Specifically, this study aims:

- To Identify and estimates the determinants of IndustryUniversity linkages in western Ethiopia.

- To examine the impact of Industry-University linkage on firm performance.

- To analyzes the impact of cooperation on the innovation probability of firms.

- To examine the factors influencing technology transfer among university and industry.

\section{Data and Methodologies}

\subsection{Data Collection Methods}

This study was conducted in western Ethiopia. The study area focus on industries located in western Ethiopia, in Illu Abba Bor Zone, Bunno Bedelle Zone and western wollega zone. The study applied purposive sampling procedure. First the industries in the in zones were categorized according to the location. Random samples of firms were then selected at the first stage and the data were then collected from the administration offices of the selected firms. On the second stage, the workers in each industry were selected and the data were collected from the selected participants

Table 1: The summary of the sample size taken for the

\begin{tabular}{|c|c|c|c|}
\hline $\begin{array}{c}\text { Administrative } \\
\text { Zone }\end{array}$ & $\begin{array}{c}\text { Sampled } \\
\text { factory }\end{array}$ & $\begin{array}{c}\text { Location of } \\
\text { the factory }\end{array}$ & $\begin{array}{c}\text { Sample } \\
\text { size }\end{array}$ \\
\hline $\begin{array}{c}\text { Bunno Bedelle } \\
\text { Zone }\end{array}$ & $\begin{array}{c}\text { Bedele Beer } \\
\text { factory }\end{array}$ & $\begin{array}{c}\text { Bedelle } \\
\text { Distinct }\end{array}$ & 40 \\
\cline { 2 - 4 } & $\begin{array}{c}\text { Bedele wood } \\
\text { factory }\end{array}$ & $\begin{array}{c}\text { Bedelle } \\
\text { Distinct }\end{array}$ & 30 \\
\hline \multirow{2}{*}{$\begin{array}{c}\text { Illu Abba Bor } \\
\text { Zone }\end{array}$} & $\begin{array}{c}\text { Gumuro tea } \\
\text { kitel factory }\end{array}$ & Alle Distinct & 35 \\
\cline { 2 - 4 } & $\begin{array}{c}\text { Bacho wood } \\
\text { factory }\end{array}$ & Bacho Distinct & 30 \\
\cline { 2 - 4 } & $\begin{array}{c}\text { Yayo faltilizer } \\
\text { factory }\end{array}$ & Yayyo Distinct & 35 \\
\hline $\begin{array}{c}\text { West Wollega } \\
\text { Zone }\end{array}$ & $\begin{array}{c}\text { Arjo didesa } \\
\text { suger factory }\end{array}$ & $\begin{array}{c}\text { Jimma arjo } \\
\text { Distinct }\end{array}$ & 40 \\
\hline Total & $\mathbf{6}$ & $\mathbf{6}$ & $\mathbf{2 1 0}$ \\
\hline
\end{tabular}

The secondary data was collected from firm Offices. On the other hand, Primary data was collected by personal interview of the employers of the firm, using a questionnaire that had been pre-tested on the workers residing in the study area.

\subsection{Variables and Methods of Data Analysis}

\subsubsection{Variables in study}

The variables included in this study were Firm Characteristics (Firm size, R\&D intensity, Reasons for Cooperation, Affiliation to Business Groups, Firm Location), Sector Characteristics, Government's support, Measuring innovation probability, Variables of Innovation outcomes (Sales, Patents, and labor productivity) and 


\section{International Journal of Science and Research (IJSR) \\ ISSN (Online): 2319-7064}

Index Copernicus Value (2015): 78.96 | Impact Factor (2015): 6.391

innovation probability of firms (P_INNO), Demand-pull and Cost-push), firm age (AGE ), export (EXPORT ), and foreign capital (FOREIGN).

\subsubsection{Methods of Data Analysis}

\section{a) Regression Analysis}

This section sets up empirical models for analysis. First, we analyze what determines a firm's propensity of IU cooperation, using the regression model. A linear regression equation of the a dependent variable IU on independent variables SIZE, RD_INT, COST and RISK, GROUP, FL, IN_IP R, G_SUP, (P_INNO), Demand-pull and Cost-push, AGE ), EXPORT, FOREIGN is given by

$$
\mathrm{IU}=\beta_{0}+\boldsymbol{\beta} \mathbf{X}+\boldsymbol{\varepsilon}
$$

Where, $\beta_{0}$, and $\boldsymbol{\beta}$, are the model parameters, $\mathrm{X}=(\mathrm{SIZE}$, RD_INT, COST and RISK, GROUP, FL, IN_IP R, G_SUP, P_INNO), IU indicates whether a firm cooperates with university. The model is specified by firm size (SIZE), R\&D intensity ( RD_INT), cooperation objective ( COST and RISK), affiliation to business groups (GROUP), firm location ( FL), IPR regime ( IN_IPR), and government's support measure ( G_SUP). Here, marginal effects are estimated at the mean point.

\section{b) Logistic Regression Analysis}

Logistic regression is a popular modeling approach when the dependent variable is dichotomous or polytomous. This model allows one to predict the log odds of outcomes of a dependent variable from a set of variables that may be continuous, discrete, categorical, or a mix of any of these. Hosmer and Lemeshow (2000) have described logistic regression focusing on its theoretical and applied aspect.

In this study, for identifying the determinants of industryuniversity linkages. $1=$ if the firm cooperates with university $=1$ and $0=$ if otherwise AND/OR $1=$ if a firm does technological innovation and 0 otherwise.

$$
I U=\left\{\begin{array}{c}
1, \text { if there is a cooperation between industry } \\
\text { and university } \\
0, \text { other wise }
\end{array}\right.
$$

\section{AND}

$I U=\left\{\begin{array}{c}1, \text { if there is technological innovation } \\ 0, \text { other wise }\end{array}\right.$

Where IU denotes industry - university, dependent variable. In logistic regression analysis, it is assumed that the explanatory variables affect the response through a suitable transformation of the probability of the success. This transformation is a suitable link function of $P$, and is called the logit-link, which is defined as:

$$
\operatorname{logit}(P)=\ln \left(\frac{P}{1-P}\right)=\beta_{0}+\boldsymbol{\beta} \boldsymbol{X}
$$

where $\beta_{0}, \beta_{1}, \beta_{2}, \ldots \beta_{\mathrm{p}}$ are the model parameters and $\mathbf{X}$ will the predictor/independent chosen variables. The transformed variable, denoted by $\operatorname{logit}(P)$ is the log-odds and is related to the explanatory variables as in equation (4).

\section{Results and Discussions}

\subsection{Empirical Analysis}

In this study, firm size (SIZE) is measured as a log value of the average number of employees during 2015-2016. The survey results show that the mean firm size is larger for firms that co operate with university (5.27). The t-ratio is $2.23(\mathrm{p}=0.03)$ for university implying the significant difference in firm size between cooperators and noncooperators. Similarly, R\&D intensity (RD_INT) is measured as a ratio of average $R \& D$ expenditure during 2015-2016 to sales in 2016. The mean of R\&D intensity is only slightly higher for firms in cooperation with university $(5.47 \%)$. The difference is not significant as seen from the $t$ ratios of each $(1.12(\mathrm{p}=0.26)$ (table 2$)$.

Actually, the mean score of these two cooperation objectives is much higher for firms that are engaged in this cooperation than otherwise (table 2): university (3.14 vs. 2.08) for costsharing objectives, and university (3.17 vs. 2.20) for risksharing objectives. The t-ratio is statistically significant for the both objectives. Therefore, we hypothesize that the more important are these cooperation objectives, the higher the firm' s propensity to cooperate with universities.

In this study, affiliation to business groups (GROUP) is measured in two ways. One is based on the answer to the following question in the survey: "Of which type is your firm among an independent company, an affiliate to domestic business groups, or an affiliates to foreign firms?" GROUP is measured as a dummy, 1 if it is either a domestic or a foreign affiliate, or 0 otherwise. The mean percentage of firms affiliated to business groups is lower for firms that cooperate with university (11.51 and 10.08), compared to the ratio among the non-cooperators (13.79 and 14.18). However, the t-ratio of each is $-0.68(\mathrm{p}=0.50)$ and -1.29 $(\mathrm{p}=0.20)$, and the difference is not statistically significant (table 2).

We take the IPR regime as a sector variable in our regression. In our study, the IPR regime variable (IN_IPR) is measured based on the answers to the following question in the survey: "How important are the following methods as means to protect IPRs of your innovation outcomes (on a five-point scale)?" Among four answered methods, patent is used for this variable. IN_IPR is measured as the industry average, universities (2.09) than otherwise (1.99), with a tratio of $3.01(p=0.0)$ (table 2$)$. This implies that firms cooperating with universities tend to use patent filing to protect their innovation outcomes than other means of protection. However, the mean score is only slightly higher for cooperators with RIs (2.07) than non-cooperators (2.00), and the difference is not statistically significant as evident in the t-ratio of $2.16(p=0.03)$. We will find out by regressions whether the IPR regime matters for the firm's propensity of IU cooperation will be done.

The variable representing the government's support ( G_SUP) is constructed based on the answers to the following question in the survey: "Which government's support measure does your firm use/participate?" Among the possible answers, whether a firm participates with national 


\section{International Journal of Science and Research (IJSR) \\ ISSN (Online): 2319-7064 \\ Index Copernicus Value (2015): 78.96 | Impact Factor (2015): 6.391}

R\&D projects or not is used for this variable. This variable take the value of 1 if a firm participates at the national R\&D projects, and 0 otherwise. If a firm participates at the national R\&D programs, a firm is entitled to get grant for R\&D expenditure in western Ethiopia, and some of them are conducted in joint projects with universities, out of conducted through industry-university cooperation, accounted for $61.2 \%$. Thus, the participation at the national projects means higher likelihood of firms' cooperative arrangement with universities. As seen from Table 2, the mean percentage of firms that use government support is higher among firms that cooperate with universities $(66.17$ and 73.13), respectively, rather than otherwise ( 30.53 and $29.67)$. The t-ratio of each is $7.95(p=0.00)$ and 9.43 ( $\mathrm{p}=0.00$ ), and thus, the difference is statistically significant. Therefore, it is hypothesized that government's supports for R\&D facilitate the firm's propensity of IU cooperation.

Table 2: Statistics on the possible determinants of IU cooperation

\begin{tabular}{|l|l|l|l|}
\hline & \multicolumn{2}{|l|}{ Industry-university cooperation } & \multirow{2}{*}{ t-test } \\
\cline { 2 - 3 } & Cooperation & Non-cooperation & \\
\cline { 2 - 3 } & $\mathrm{N}=2$ & $\mathrm{~N}=4$ & \\
\hline Firm size (log of employees) & 5.27 & 5.02 & $2.23(0.03)^{* *}$ \\
\hline R\&D intensity (\%) & 5.47 & 2.99 & $1.12(0.26)$ \\
\hline \% of firms belonging to business groups & 11.51 & 13.78 & $-0.68(0.50)$ \\
\hline Cost-sharing objective (point) & 3.14 & 2.08 & $8.58(0.00)^{* * *}$ \\
\hline Risk-sharing objective (point) & 3.17 & 2.20 & $7.72(0.00)^{* * *}$ \\
\hline $\begin{array}{l}\text { \% of firms participating in national } \\
\text { R\&D projects }\end{array}$ & 66.1730 .53 & 30.53 & $7.95(0.00)^{* * *}$ \\
\hline IPR regime (point) & 2.091 .99 & 1.99 & $3.01(0.00)^{* * *}$ \\
\hline
\end{tabular}

Note: The numbers in parenthesis present $\mathrm{p}$-value. ${ }^{* * *}, * *$, and $*$ represent $1 \%, 5 \%$, and $10 \%$ levels of significance, respectively.

\subsection{Measuring innovation probability}

In this study, innovation probability is measured as 1 if a firm does technological innovation and 0 otherwise. In western Ethiopia, $33.33 \%$ or 2 out of a total of 6 firms cooperate with university, of which $74.2 \%$ or 2 firms do technological innovation. However, $66.67 \%$ or 4 out of 6 firms, which have no cooperation with it, do technological innovation, which of $33.33 \%$ or 1 one firm do technological innovation (table 3 ).

Table 3: Industry-University cooperation and technological innovation

\begin{tabular}{|c|c|c|c|}
\hline & \multicolumn{2}{|c|}{ Universities } & \multirow{2}{*}{ t-statistics } \\
\cline { 2 - 3 } & $\begin{array}{c}\text { Cooperators } \\
(\mathrm{n}=2)\end{array}$ & $\begin{array}{c}\text { Non-cooperators } \\
(\mathrm{n}=4)\end{array}$ & \\
\hline $\begin{array}{c}\text { No. (\%) of } \\
\text { innovative firms }\end{array}$ & $2(74.2 \%)$ & $1(16.67 \%)$ & $7.58(0.00)^{* *}$ \\
\hline
\end{tabular}

Note: The numbers in parenthesis present $\mathrm{p}$-value. $* * *, * *$, and $*$ represent $1 \%, 5 \%$, and $10 \%$ levels of significance, respectively.

\subsection{Variables of Innovation outcomes: Sales, Patents, and labor productivity}

In this study, innovation performance is measured in three ways: 1) the number of patents filed from the three finds of innovation together as well as from each type of innovation, 2) share of sales revenue associated with product innovation, 3) labor productivity. In terms of the average number of patents filed from technological innovation, overall, it is higher for cooperators (7.22) than non-cooperators (5.31) with universities.
Table 4: Industry-university cooperation and firm performance

\begin{tabular}{|c|c|c|c|}
\hline & \multicolumn{3}{|c|}{ Universities } \\
\cline { 2 - 4 } & Cooperators & $\begin{array}{c}\text { Non- } \\
\text { Cooperators }\end{array}$ & t-test \\
\hline Patent (No.) & 7.22 & 5.31 & $0.67(0.50)$ \\
\hline Sale (\%) & 48.62 & 44.90 & $1.08(0.28)$ \\
\hline $\begin{array}{c}\text { labor productivity } \\
\text { (No., average) }\end{array}$ & $92,200.00$ & $80,200.00$ & $0.12(0.90)$ \\
\hline
\end{tabular}

Note: The numbers in parenthesis present $\mathrm{p}$-value. ***,**, and $*$ represent $1 \%, 5 \%$, and $10 \%$ levels of significance, respectively.

In terms of the number of patents filed as outcomes of new product development, firms cooperating with universities tend to generate more patents than non-cooperating firms: 2.22 vs. 1.20 in industry-university cooperation comparison. The difference measured by t-statistics is significant with $2.22(\mathrm{p}=0.02)$ for cooperation with university. However, in spite of a larger number of firms engaged in process innovation than product innovation, much less number of patents are generated by both cooperating and noncooperation firms. It might make sense when we consider the different nature of process innovation compared to product innovation. Also, no significant difference is found between the cooperating and non-cooperating firms (table $5)$.

Table 5: Industry-University cooperation and firm performance (No. of patents filed)

\begin{tabular}{|c|c|c|c|}
\hline & \multicolumn{3}{|c|}{ Universities } \\
\cline { 2 - 4 } & Cooperators & $\begin{array}{c}\text { Non- } \\
\text { Cooperators }\end{array}$ & t-test \\
\hline $\begin{array}{c}\text { New product } \\
\text { innovation }\end{array}$ & 2.22 & 1.20 & $2.22(0.02)^{* *}$ \\
\hline $\begin{array}{c}\text { Product improving } \\
\text { innovation }\end{array}$ & 2.12 & 2.77 & $-0.41(0.68)$ \\
\hline Process innovation & 0.65 & 1.26 & $-0.59(0.56)$ \\
\hline
\end{tabular}




\section{International Journal of Science and Research (IJSR) \\ ISSN (Online): 2319-7064}

Index Copernicus Value (2015): 78.96 | Impact Factor (2015): 6.391

\subsection{Regression Analysis}

The linear regression equation characterizing the effect of firm size (SIZE), R\&D intensity (RD_INT), cooperation objective (COST and RISK), affiliation to business groups (GROUP), firm location ( $r \_S$ ), IPR regime (IN_IPR), and government's support measure (G_SUP), age of firm (AGE) on Industry-university (IU) cooperation, indicates whether a firm cooperates with university: 1 if the firm cooperates with them and 0 otherwise. The model is specified by

$$
\begin{gathered}
I U=32.30+1.25 S I Z E+2.1 C O S T+4.2 R I S K+ \\
2.1 G R O U P+3.2 I N \_I P R+2 G \_S U P \text {-------- }(5)
\end{gathered}
$$

As it can be seen from equation (5), the rate of Industryuniversity (IU) cooperation is increases with increasing of Size of the firm, Cost-sharing, risk-sharing, business group, IPR regime, and government support where as other variables, location of the firm and age of the firm were insignificant.

The cost-sharing motives are more important and significant for linkages with universities. This might reflect the situation in western Ethiopia that GRIs in general have more financial resources than universities with more direct and regular support from the government budget. In contrast, firms seem to cooperate with universities to get help from knowledge of instructors and student and thereby save the cost of man power.

As we can see from eq (5), firm characteristics variables of SIZE and R\&D intensity ( RD_INT), government support variable ( G_SUP) are statistically significant cooperation modes. This implies large firm is more cooperated to the university than small size. The government support also positive statistically significant variable. Increasing the government support in reveals the cooperation among the industry and universities.

\section{The Determinants of Industry-University Cooperation}

This part analyzes the determinants of IU cooperation, using the Probit model. The dependent variable measures whether a firm cooperates with universities, for its innovation effort: the variable is 1 if it does and 0 otherwise.

IU reveals a significantly positive sign implying a significant impact of the IU cooperation on innovation possibility. But, this result change when endogeneity is controlled. Based on the result, we can say that the significance of IU in the first step reflects the endogeneity such that more innovative firms tend to pursue collaboration with universities, not the other way around.

Regarding the other variables, the variable of the government support ( G_SUP) indicating participation at the national $R \& D$ programs is shown to be positive and significant, which again underscores the importance of the government initiatives to promote innovation in private firms. Besides this, the demand-pull and cost-push factors are shown to be statistically significant, which implies that firms tend to innovate either to increase market shares and improve product quality ( demand pull) or to reduce the costs of material or labor inputs ( cost-push ). EXPORT is also statistically positive, implying that export-oriented firms tend to do technological innovation. Somewhat surprisingly, the impact of R\&D intensity ( $R D \_I N T$ ) is shown to be obscure. This result may be related to the possibility that due to contemporaneous nature of regressions now allowing for lagged impacts the impact of today's R\&D might not show up affecting today's innovation success possibility (table 6).

Table 6: Impacts of Industry-university on the innovation probability using probit model

\begin{tabular}{|l|l|l|l|l|l|l|l|l|l|}
\hline Variables & SIZE & RD_INT & GROUP & COST & RISK & G_SUP & Demand-pull & Cost-push & EXPORT \\
\hline IU cooperation & 0.03 & -1.56 & 0.00 & 0.12 & 0.08 & 0.21 & 0.42 & 0.17 & 0.23 \\
& $(0.28)$ & $(-2.37)$ & $(0.02)$ & $(1.24)$ & $(0.83)$ & $(1.05)$ & $(4.85)^{* *}$ & $(2.11)^{* *}$ & $(1.18)$ \\
\hline
\end{tabular}

Note: The numbers in parenthesis present p-value. ***,**, and $*$ represent $1 \%, 5 \%$, and $10 \%$ levels of significance, respectively.

Based on this result, regarding the hypothesis, we conclude that the IU cooperation does not seem to be the triggering factor for the probability of innovation success. Rather, successful innovation seems to be affected by direct government support program, as well as traditional factor $\mathrm{s}$ like cost-push and demand-pull factors.

Finally, the results of the study examine the impact of the IU cooperation on different indicators of firm performance. The coefficient of IUG is not statistically significant at all for all the three indicators of the number of patents, sale, and labor productivity, either in the industry-university case. This implies that this cooperation has no significant impact on firm performance overall, which is consistent with the preceding results on the impact of the IU cooperation on innovation probability. The result is different from the case of advanced countries where industry-university cooperation contributes to the sales of innovation outcomes as well as the number of patents filed.

\section{Conclusion and Recommendation}

\subsection{Conclusion}

Given the increasing importance of knowledge and universities as the source of new knowledge, this paper has investigated the role of firms' cooperation with universities in the NIS of an emerging economy of Ethiopia. As a fast catching-up economy, the NIS of Ethiopia has been unbalanced or immature with strong dominance by the government. These unique characteristics of the Ethiopia NIS have left its knowledge industrialization systems underdeveloped, compared to those in the advanced countries.

This utilizes the 2015 - 2016 western Ethiopia Innovation Survey data to find out the determinants of industryuniversity cooperation and its impact on firm performance.

\section{Volume 6 Issue 1, January 2017 www.ijsr.net}




\section{International Journal of Science and Research (IJSR) \\ ISSN (Online): 2319-7064}

Index Copernicus Value (2015): 78.96 | Impact Factor (2015): 6.391

Regarding the latter, it has focused on innovation probability and on sale vs. patent (by the type of performance) and product innovation vs. process innovation (by the type of innovation ). The main findings are as follows.

First, among determinants of IU cooperation, traditional firm characteristics variables of sizes and R\&D intensity, cooperation objective (COST and RISK), affiliation to business groups (GROUP), IPR regime (IN_IPR), and government's support measure (G_SUP), age of firm (AGE) are significant at all, whereas firm location and age of the firm is not significant. As difference between the mode of cooperation, we find that cost-sharing and risk-sharing motives are more important for the industry-university mode.

Second, regarding the impacts of the IU cooperation, we strikingly find no significant impact on the innovation probability of firms when we control the possible endogeneity such that already innovative firms might participate more at such cooperation modes. This implies that the IU cooperation cannot guarantee a firm success in technological innovation; rather, it may have an influence on the selection or direction of the firm's research projects.

When we limit the analysis to the innovative firms, we do find positive impacts of the IU cooperation on patents generated from new product innovation but no impacts in terms of sales increase or labor productivity. These results seem to reflect the still transitional nature of the NIS and knowledge industrialization such that knowledge industrialization (innovation leading to sales or productivity) has not been fully progressed, and also reflect the nature of government-sponsored IU program where the number of generated patents was given high priority as evaluation criteria. Also, significant increase of patents from new product innovation rather than product-improving or process innovation seems to reflect the characteristics of the research by Ethiopian universities as being oriented toward more radical innovation.

It is also interesting to note that the $\mathrm{R} \& \mathrm{D}$ intensity is positively related to the number of patents and sales associated with new product and process innovation, whereas it was not significant in the regressions on innovation probability or as determinants of the IU cooperation. These results together implies that while more R\&D intensity cannot guarantee the success of innovation effort but it is positively associated with certain types of patents or sales when there is successful innovations.

\subsection{Recommendation}

Based on the results discussed above, the researcher would like to forward the following recommendations:-

1) The government should increases the support of the industries as they can cooperate with the university and link with foreign countries.

2) The firms should maximize the size, implies increasing the number of workers (employee) in the industry. This makes as the firm communicate with the governments and universities.
3) Increasing the group work among the industries and universities. This increases the knowledge exchanges, save human power for the firm and technology transfer.

4) Creating the awareness about the technology transfer for both universities and industries and facilitating conditions so that the industry will cooperate with university.

\section{Acknowledgement}

The authors gratefully acknowledged the anonymous reviewers for their contributions towards this work.

\section{References}

[1] Calvert, J. and P. Patel (2012): "University-industry research collaboration sin the UK: bibliometric trends", Science and Public Policy 30 (2): 85-96.

[2] Capron, H. and M. Cincera. (2003). Industry-University S\&T Transfers: Belgium Evidence on CIS Data. Brussels Economic Review , 46(3), 58-85.

[3] Chang, Sea Jin and Jaebum Hong. (2010). Economic Performance of Group-Affiliated Companies in Korea: Intragroup Resource Sharing and Internal Business Transactions. Academy of Management Journal, 43(3), 429-448.

[4] Etzkowitz, H. and L. Leydesdorff (2000). "The dynamics of innovation: from National Systems and "Mode 2" to a Triple Helix of university-industrygovernment relations". Research Policy 29: 109-123.

[5] Freel, M. S. and R. T. Harrison. (2006). Innovation and Cooperation in the Small Firm Sector: Evidence from Northern Britain. Regional Studies , 40(4), 289-305.

[6] Freeman, C. (2006). Technology Policy and Economic Performance: The Theory and an Application to the Semiconductor Industry. (London: Macmillan).

[7] Gibbons and Johnston. (2006). The Roles of Science in Technological Innovation, in P. E. Stephan (ed). The Economics of Science and Innovation. (Northampton, MA: Elgar).

[8] Hall, B.H., A.N. Link and J.T. Scott (2010): "Barriers inhibiting industry from partnering with universities: evidence from the advanced technology program", Journal of Technology Transfer 26: 87-98.

[9] Martin, S. and J.T. Scott (2007): "The nature of innovation market failure and the design of public support for private innovation", Research Policy 29: 437-447.

[10]Monjon, Stephanie and Patrick Waelbroeck. (2014). Assessing Spillovers from Universities to Firms: Evidence from French Firm-level Data. International Journal of Industrial Organization, 21, 1255-1270.

[11] Rouvinen, Petri. (2002). Characteristics of Product and Process Innovators: Some Evidence from the Finnish Innovation Survey. Applied Economics Letters , 9, 575-580. 